\title{
Evaluation of the adsorption potential of biochars prepared from forest and agri-food wastes for the removal of fluoxetine
}

\author{
Maria João Fernandes ${ }^{\mathrm{a}, \mathrm{b}}$, Manuela M. Moreira ${ }^{\mathrm{a}, *}$, Paula Paíga $^{\mathrm{a}}$, Diogo Dias ${ }^{\mathrm{c}}$, Maria Bernardo ${ }^{\mathrm{c}}$, \\ Manuela Carvalho ${ }^{\mathrm{a}}$, Nuno Lapa ${ }^{\mathrm{c}}$, Isabel Fonseca ${ }^{\mathrm{c}}$, Simone Morais ${ }^{\mathrm{a}}$, Sónia Figueiredo ${ }^{\mathrm{a}}$, \\ Cristina Delerue-Matos ${ }^{\mathrm{a}}$
}

\footnotetext{
${ }^{a}$ REQUIMTE/LAQV, Instituto Superior de Engenharia do Instituto Politécnico do Porto, Rua Dr. António Bernardino de Almeida, 431, 4249-015 Porto, Portugal ${ }^{\mathrm{b}}$ IIT/LTA - Instituto de Investigaciones Tecnológicas, Universidad de Santiago de Compostela, E-15782 Santiago de Compostela, Spain

${ }^{\mathrm{c}}$ LAQV/REQUIMTE, Faculdade de Ciências e Tecnologia (FCT), Universidade Nova de Lisboa (UNL), 2829-516 Caparica, Portugal
}

\begin{abstract}
A B S T R A C T
Twelve biochars from forest and agri-food wastes (pruning of Quercus ilex, Eucalyptus grandis, Pinus pinaster, Quercus suber, Malus pumila, Prunus spinosa, Cydonia oblonga, Eriobotrya japonica, Juglans regia, Actinidia deliciosa, Citrus sinensis and Vitis vinifera) were investigated as potential low-cost and renewable adsorbents for removal of a commonly used pharmaceutical, fluoxetine. Preliminary adsorption experiments allowed to select the most promising adsorbents, Quercus ilex, Cydonia oblonga, Eucalyptus, Juglans regia and Vitis vinifera pruning material. They were characterized by proximate, elemental and mineral analysis, thermogravimetric analysis, Fourier transform infrared spectroscopy, determination of specific surface area and $\mathrm{pH}$ at the point of zero charge. Batch and equilibrium studies were performed, and the influence of $\mathrm{pH}$ was evaluated. The equilibrium was reached in less than $15 \mathrm{~min}$ in all systems. The maximum adsorption capacity obtained was $6.41 \mathrm{mg} / \mathrm{g}$ for the Eucalyptus biochar, which also demonstrated a good behavior in continuous mode (packed column).
\end{abstract}

Keywords:

Anti-depressant pharmaceutical

Biochar

Column experiments

Kinetics and equilibrium

Waste valorization

\footnotetext{
Abbreviations: EA, elemental analysis; FLX, fluoxetine; FTIR, Fourier transform infrared spectroscopy; HPLC-FLD, high-performance liquid chromatography with fluorescence detection; RMSE, root mean square error; RPM, rotation per minute; SD, standard deviation; TGA, thermogravimetric analysis

* Corresponding author at: REQUIMTE/LAQV, Instituto Superior de Engenharia do Porto, Instituto Politécnico do Porto, Rua Dr. António Bernardino de Almeida, 431, 4200-072 Porto, Portugal.

E-mail address: manuela.moreira@graq.isep.ipp.pt (M.M. Moreira).
} 


\section{Introduction}

Pharmaceutical products and their active compounds are among the most found environmental contaminants, being characterized by their persistency and biological activity (Biel-Maeso et al., 2018). Their appearance in the environment depends on several factors, such as the consumption by human population and animals and the removal efficiency in wastewater treatment plants (WWTP), being spotted in aquatic environment and soil (Biel-Maeso et al., 2018; Paíga et al., 2019). Fluoxetine (FLX) is an anti-depressant pharmaceutical widely used to treat depression (Silva et al., 2014). Since only a fraction of this compound is metabolized by human body, much of it (and its metabolites) may end up in domestic wastewaters. As the conventional wastewater treatment systems are not specifically designed for the removal of pharmaceutical active compounds, it is crucial to develop remediation strategies.

Since FLX was designed to produce a specific pharmacological response, it presents a certain chemical stability which is related with its insufficient removal in municipal WWTP and limited environmental degradation (Silva et al., 2012). This compound is relatively recalcitrant to hydrolysis, photolysis, and biodegradation (Redshaw et al., 2008).

An effective tertiary treatment for removal of pharmaceuticals is adsorption (Cobas et al., 2016; Silva et al., 2018), however, its use has been limited as the adsorbent material can represent a high operational cost for wastewater treatment systems. Therefore, there is a need to search for cheaper alternatives. Recently, biochar materials have been shown to be promising solutions owing to their low cost, and high adsorption efficiency (Ahmed et al., 2016; Oliveira et al., 2017; Rosales et al., 2017).

Many agricultural and industrial activities generate large quantities of biomass wastes. Biochar production from these wastes is currently one of the most innovative fields of research (Oliveira et al., 2017; Tripathi et al., 2016; Turk Sekulić et al., 2018). Biochar is a carbonaceous solid material obtained by pyrolysis of several feedstocks, including lignocellulosic wastes, such as wood, prunings, leaves, grass or other biomass from forest and agricultural origin. The main chemical and physical properties of biochars towards their application as adsorbent material are their relatively high porosity and specific surface area, high surface charge and high water holding capacity (Oliveira et al., 2017; Turk Sekulić et al., 2018).

Several authors have reported that the use of biochars for the removal of toxic substances from industrial wastewaters represents an effective and affordable method, especially in what concerns small volumes of highly concentrated liquid waste streams (Oliveira et al., 2017). Moreover, they can also improve physical, chemical, and biological properties of soils (Bis et al., 2018; Fryda and Visser, 2015; Laghari et al., 2016; Lehmann et al., 2011; Liao et al., 2018; Yu et al., 2019). The properties of biochars depend on the type of feedstock used and the pyrolysis settings, such as the residence time, temperature, heating rate, and reactor type (Bis et al., 2018; Yu et al., 2019). Depending on the target pollutant, biochar and activated carbon efficiencies might be comparable. However, biochar production is ecofriendly and less expensive than the typical activated carbons that require costly and energy consuming activation processes (Ahmad et al., 2014).

The present work aims to investigate the effectiveness of FLX adsorption capacity by different biochars produced from forest and agrifood wastes, namely pruning of several forest trees, orchard trees and vineyards. Usually, these types of wastes are characterized concerning their bioactivities for further application in the food, pharmaceutical and/or cosmetic industries (Moreira et al., 2017, 2018). According to authors' knowledge, there are no published reports on their use for biochar production and subsequent application for removal of FLX from aqueous solutions. With this purpose, twelve biomass wastes, namely pruning from Quercus ilex L. (hollow tree), Eucalyptus grandis W. Hill ex
Maiden (eucalyptus), Pinus pinaster Ainton. (pine), Quercus suber L. (cork tree), Malus pumila Mill. (apple tree), Prunus spinosa L. (blackberry tree), Cydonia oblonga Mill. (quince), Eriobotrya japonica (Thunb.) Lindl (medlar tree), Juglans regia L. (walnut tree), Actinidia deliciosa Liang and Ferguson (kiwi shrub), Citrus sinensis (L.) Osbeck (orange tree) and Vitis vinifera $\mathrm{L}$. (vine), were submitted to pyrolysis under the same controlled conditions (temperature, oxygen and residence time). After the preliminary assays to evaluate the biochars' uptake capacity for FLX, five materials were selected and studied in detail, namely for physico-chemical parameters, kinetic and equilibrium assays in batch mode. Continuous studies in packed column were also carried out for the best adsorbent (eucalyptus biochar) in order to demonstrate its efficacy under dynamic conditions.

Ex situ thermal processes for adsorbent regeneration are highly efficient, but the number of regeneration cycles is reduced, especially for small particles, as is the case of biochars. Electrochemical regeneration processes may be an interesting alternative to be studied, that can be performed in situ.

\section{Materials and methods}

\subsection{Chemicals}

FLX hydrochloride ( $>98 \%$ ) was purchased from Sigma-Aldrich (Steinheim, Germany). A FLX stock standard solution $(1000 \mathrm{mg} / \mathrm{L})$ was prepared by dissolving an appropriate amount of the reagent in methanol and stored at $-20^{\circ} \mathrm{C}$ in a dark glass vial. Dilutions of this solution were prepared with HPLC-grade water, obtained from purification of deionized water in a Simplicity 185 system (Millipore, Molsheim, France). Hydrochloric acid and sodium hydroxide (purity $>99.0 \%$ ), used for $\mathrm{pH}$ adjustments, were obtained from VWR. HPLC-gradient grade acetonitrile and formic acid $(\mathrm{HCCOH}$, purity 99-100\%), used for the preparation of HPLC eluents, were from VWR Chemicals BDH Prolabo, PA, USA.

\subsection{Biochar preparation}

Twelve different types of biomass wastes from different vegetal species, namely pruning from Quercus ilex L. (hollow tree), Eucalyptus grandis W. Hill ex Maiden (eucalyptus), Pinus pinaster Ainton. (pine), Quercus suber L. (cork tree), Malus pumila Mill. (apple tree), Prunus spinosa L. (blackberry tree), Cydonia oblonga Mill. (quince), Eriobotrya japonica (Thunb.) Lindl (medlar tree), Juglans regia L. (walnut tree), Actinidia deliciosa Liang and Ferguson (kiwi shrub), Citrus sinensis (L.) Osbeck (orange tree) and Vitis vinifera L. (vine), were kindly provided by Ibero Massa Florestal Company (Portugal) and used to produce the biochars. The different biomass wastes were pyrolyzed in an industrial oven from Ibero Massa Florestal (Portugal): $8 \mathrm{~h}$ of heating time, $14 \mathrm{~h}$ of holding at $500{ }^{\circ} \mathrm{C}$ and cooling for $18 \mathrm{~h}$ until room temperature. The pyrolysis was made without any gas supply (nitrogen or carbon dioxide). There is a minimum volume of air remaining between the biomass pieces, just after closing the oven that is consumed immediately when the temperature increases. Therefore, the process undergoes in the absence of molecular oxygen, being present only the oxygen constituting the biomass.

Prior to use, the obtained biochars were grounded in a cutting mill (Type GBA 0301, Ferrari) and sieved to obtain a material of a uniform particle size. The fraction with a particle diameter $<75 \mu \mathrm{m}$ was selected for the experiments.

\subsection{Biochar characterization}

The characterization of biochars was only performed for the selected biochars, based on their FLX adsorption capacity, namely Quercus ilex L. (hollow tree), Cydonia oblonga Mill. (quince), Eucalyptus grandis W. Hill ex Maiden (eucalyptus), Juglans regia L. (walnut tree) and Vitis 
vinifera $\mathrm{L}$. (vine) pruning material.

The laser diffraction method was applied to perform the granulometric analyses using a Mastersizer Hydro 2000G (Malvern Instruments, UK), a laser diffraction granulometer attached to a dispersion unit, capable to analyze particle sizes between $20 \mathrm{~nm}$ and $2 \mathrm{~mm}$. The refractive index for the dispersed phase was 2.42 and the particle absorption index was 1 . The amount of sample used to the analysis was such that the value of obscurance fell within the range of $10-20 \%$. The continuous phase was water with a refractive index of 1.330 , the pump speed was set at $1250 \mathrm{rpm}$ and the stirrer speed at $600 \mathrm{rpm}$, ensuring homogenization.

Elemental analysis (quantification of carbon, hydrogen, nitrogen and sulphur contents) was performed in an Elemental Analyzer Thermo Finnigan - CE Instruments, model Flash EA 1112 CHNS series, based on sample combustion dynamics. The proximate analysis that included the quantification of moisture content, volatile matter and ashes followed the ASTM D1762 standard, which is specifically designed for wood charcoal.

Thermogravimetric analysis (TGA) was performed in a Setaram Labsys EVO equipment, between room temperature and $850^{\circ} \mathrm{C}$, with a heating rate of $5^{\circ} \mathrm{C} / \mathrm{min}$, under argon atmosphere.

Fourier transform infrared spectroscopy (FTIR) analyses were performed in a Perkin-Elmer - Spectrum 1000 spectrophotometer, using the potassium bromide $(\mathrm{KBr})$ disc method (biochar: $\mathrm{KBr}$ ratio of around 1:200). The spectra were recorded from 400 to $4000 \mathrm{~cm}^{-1}$ with the resolution of $1 \mathrm{~cm}^{-1}$.

The $\mathrm{pH}$ at the point of zero charge $\left(\mathrm{pH}_{\mathrm{pzc}}\right)$ for the selected biochars was determined according to the following methodology (Carabineiro et al., 2012): $0.1 \mathrm{~g}$ of biochar was added to $20 \mathrm{~mL}$ of $0.1 \mathrm{M} \mathrm{NaCl}$ solutions with initial $\mathrm{pH}$ values between 2.0 and 12.0 (pH adjustment was performed with solutions of $\mathrm{NaOH}$ or $\mathrm{HCl}$ with concentrations of $0.01-1 \mathrm{M}$ ); the mixtures were stirred for $24 \mathrm{~h}$ and the final $\mathrm{pH}$ was measured; $\mathrm{pH}_{\mathrm{pzc}}$ value corresponds to the plateau of the curve $\mathrm{pH}_{\text {final }} v s$ $\mathrm{pH}_{\text {initial }}$.

The determination of the mineral content was performed according to the European Standard EN 15290 (2011) on samples previously digested $\left(3 \mathrm{~mL} \mathrm{H}_{2} \mathrm{O}_{2} 30 \% \mathrm{v} / \mathrm{v}+8 \mathrm{~mL} \mathrm{HNO}_{3} 65 \% \mathrm{v} / \mathrm{v}+2 \mathrm{~mL} \mathrm{HF} 40 \% \mathrm{v} /\right.$ $\mathrm{v})$ in a microwave station (Milestone Ethos 1600 Microwave Labstation) followed by neutralization $\left(20 \mathrm{~mL} \mathrm{H}_{3} \mathrm{BO}_{3} 4 \% \mathrm{w} / \mathrm{v}\right)$; the acidic solutions were analysed by Inductively Coupled Plasma - Atomic Emission Spectroscopy (ICP-AES) (Horiba Jobin-Yvon equipment) for the quantification of the most common chemical elements in biochars: $\mathrm{Ca}, \mathrm{K}, \mathrm{Na}$, $\mathrm{Fe}, \mathrm{Mg}, \mathrm{Al}, \mathrm{Cr}, \mathrm{Ni}, \mathrm{Cu}, \mathrm{Zn}$.

Textural parameters such as apparent surface area $\left(\mathrm{S}_{\mathrm{BET}}\right)$ and total pore volume $\left(\mathrm{V}_{\text {total }}\right)$ were evaluated from the adsorption of $\mathrm{N}_{2}$ at $77 \mathrm{~K}$ (ASAP 2010 Micromeritics equipment) by using the single point method at the relative pressure of $\mathrm{P} / \mathrm{Po}=0.3$; all samples were previously outgassed overnight, under vacuum, at $150{ }^{\circ} \mathrm{C}$ before analysis.

\subsection{Preliminary adsorption assays}

Preliminary adsorption studies were performed in the twelve different biochars by placing $0.25 \mathrm{~g}$ of each biochar in $25 \mathrm{~mL}$ of solution containing $20 \mathrm{mg} / \mathrm{L}$ of FLX in Erlenmeyer flasks; the flasks were closed and magnetically stirred at $400 \mathrm{rpm}$ (Multistirrer 15, Velp Scientifica) for $2 \mathrm{~h}$ at room temperature $\left(25^{\circ} \mathrm{C}\right)$ without $\mathrm{pH}$ adjustment. At the end of the experiments, an aliquot of the final solutions were immediately centrifuged (Heraeus Fresco 21 Microcentrifuge, Thermo Scientific, USA) at $14,500 \mathrm{rpm}$, for $10 \mathrm{~min}$, at $4^{\circ} \mathrm{C}$, which ensure that all solid is separated from the supernatant (Piccirillo et al., 2017). The supernatant was analyzed by HPLC to determine the final concentration of the FLX, as described in Section 2.9. In parallel, blank assays were prepared with the same FLX concentration and without biochar. The assays were performed in triplicate, and the results were expressed as mean and standard deviation (SD). The percentage of adsorbate removal $(R, \%)$ was calculated from the equation (1):
$R=\frac{\left(C_{0}-C_{f}\right)}{C_{0}} \times 100$

where $C_{o}$ and $C_{f}(\mathrm{mg} / \mathrm{L})$ represent the initial and final concentration of the FLX (determined by HPLC) after $2 \mathrm{~h}$ stirring.

\subsection{Kinetic assays}

For the kinetic experiments, $0.75 \mathrm{~g}$ of biochar in $250 \mathrm{~mL}$ of solution containing $20 \mathrm{mg} / \mathrm{L}$ of FLX were used and stirred at $400 \mathrm{rpm}$ (VMS - C7 advanced, VWR) during $60 \mathrm{~min}$ at room temperature. The contact time was chosen taking in consideration the results obtained in previous kinetic studies with biochars. An aliquot of $1 \mathrm{~mL}$ was collected every minute, centrifuged and analyzed as described in Section 2.4 in order to determine the remaining concentration of FLX in solution along time.

The mass of FLX adsorbed per gram of adsorbent $\left(q_{t}, \mathrm{mg} / \mathrm{g}\right)$ was calculated according to Eq. (2):

$q_{t}=\left(C_{0}-C_{e}\right) \times \frac{V}{m}$

where $C_{o}$ and $C_{e}(\mathrm{mg} / \mathrm{L})$ are the initial and equilibrium concentrations of FLX, $V(\mathrm{~L})$ is the volume of the FLX solution and $m(\mathrm{~g})$ is the mass of biochar.

The $\mathrm{pH}$ was recorded (Consort $\mathrm{pH}$ Meter model C861, Belgium) during the experiments.

\subsection{Effect of $p H$}

The effect of initial $\mathrm{pH}$ was evaluated only for the three most promising biochars, namely for hollow tree, eucalyptus and vine. For this purpose, $0.04 \mathrm{~g}$ of eucalyptus and $0.08 \mathrm{~g}$ of hollow tree or vine were placed in flasks with $25 \mathrm{~mL}$ of a $20 \mathrm{mg} / \mathrm{L}$ aqueous solution of FLX. The $\mathrm{pH}$ in each suspension was adjusted in a range from 4 to 7 by using $0.01 \mathrm{~mol} / \mathrm{L} \mathrm{HCl}$ or $0.1 \mathrm{~mol} / \mathrm{L} \mathrm{NaOH}$ solutions. The flasks were stirred at $400 \mathrm{rpm}$ (Multistirrer 15, Velp Scientifica) for $120 \mathrm{~min}$, although it was known that equilibrium was reached in less than $15 \mathrm{~min}$. Samples of $1 \mathrm{~mL}$ were collected and centrifuged at time 0,15 and $120 \mathrm{~min}$, the $\mathrm{pH}$ was measured and the FLX concentration was determined as described in Section 2.4. A blank test (without the addition of biochar) was done for each $\mathrm{pH}$ investigated.

Additionally, another assay was also carried out to evaluate the $\mathrm{pH}$ influence, where the biochar and water were in contact for $2 \mathrm{~h}$ allowing the leaching of species that could interfere with the $\mathrm{pH}$ value of the solution. Then, the $\mathrm{pH}$ solution was adjusted to 7.0 and let stand for $1 \mathrm{~h}$. Only after these steps, the FLX was added and the assay was conducted.

\subsection{Equilibrium assays}

Adsorption isotherms were obtained by using different quantities of the adsorbent, ranging from 10 to $400 \mathrm{mg}$, in flasks with $25 \mathrm{~mL}$ of a $20 \mathrm{mg} / \mathrm{L}$ aqueous solution of FLX. The mixtures were stirred (Multistirrer 15, Velp Scientifica) for $15 \mathrm{~min}$ (time enough to reach equilibrium) at room temperature. Then, samples were centrifuged and FLX concentration was determined as described in Section 2.4.

Two commonly used adsorption isotherm models, Langmuir and Freundlich, were used to adjust the experimental values.

The Langmuir's model assumes a monolayer adsorption over an energetically homogeneous adsorbent surface. It does not take into consideration interactions between adsorbed molecules and is represented by Eq. (3) (Langmuir, 1918):

$q_{e}=\frac{\left(Q_{m} \cdot k_{L} \cdot C_{e}\right)}{\left(1+k_{L} \cdot C_{e}\right)}$

where $C_{e}$ is the equilibrium concentration of adsorbate $(\mathrm{mg} / \mathrm{L}), q_{e}$ is the adsorption capacity at equilibrium (mg/g), $K_{L}$ is the Langmuir equilibrium constant related to the energy of adsorption $(\mathrm{L} / \mathrm{mg})$, and $Q_{m}$ is 
the maximum adsorption capacity (mg/g), which in this model should corresponds to a monolayer coverage of the adsorbent surface.

Freundlich's isotherm is an empirical model that assumes the existence of heterogeneous adsorption centers on the surface of the adsorbent. It is represented by the Eq. (4) (Freundlich, 1907):

$q_{e}=K_{F} \cdot C_{e}^{1 / n}$

where $K_{F}$ is the Freundlich isotherm constant $\left.\left[(\mathrm{mg} / \mathrm{g})(\mathrm{L} / \mathrm{mg})^{1 / \mathrm{n}}\right)\right]$, and $n$ (dimensionless) is the Freundlich exponent which describes the strength of adsorption. Typically, $1 / n$ value ranges between 0 and 1 , and if $1 / n$ is closer to 0 , the adsorption intensity is higher.

Isotherm parameters, correlation coefficients $\left(\mathrm{R}^{2}\right)$ and root mean square error (RMSE) for Langmuir and Freundlich models were obtained by Microsoft Excel for Windows 2010 with XLSTAT Version 2018.7.

\subsection{Column assays}

A glass column (Omnifit) $(15 \mathrm{~cm}$ maximum height and $2.5 \mathrm{~cm}$ of internal diameter) and a peristaltic pump (Gilson, Minipuls 3) were used. The column was filled up with $4.0 \mathrm{~g}(15 \mathrm{~mL})$ of biochar eucalyptus and $50.6 \mathrm{~g}(25 \mathrm{~mL})$ of washed silica sand. The sand was used as dispersive material, half of it was placed below and the other half above the biochar. A continuous down-flow rate of $2.033 \mathrm{~mL} / \mathrm{min}$ was employed. The assays were performed at room temperature and a $20 \mathrm{mg} / \mathrm{L}$ aqueous solution of FLX was used. Samples were periodically taken from the outflow, and they were analyzed as described in Section 2.9.

Three models, namely Thomas's, Yoon-Nelson's and Yan's models, were used to adjust the experimental data.

The Thomas's model is one of the most widely used column performance models which allows to predict the relationship between concentration and time, and is represented by Eq. (5) (Thomas, 1944):

$\frac{C}{C_{0}}=\frac{1}{1+\exp \left(\frac{k_{T h} Q_{0} m}{F}\right) k_{T h} C_{0} t}$

Where $C_{o}$ is the initial concentration of FLX, $C$ is the FLX concentration at time $t(\mathrm{mg} / \mathrm{L}), Q_{0}$ is the maximum adsorption capacity of the adsorbent $(\mathrm{mg} / \mathrm{g}), m$ is the amount of adsorbent $(\mathrm{g}), F$ is the flow rate $(\mathrm{mL} / \mathrm{min}), t$ is the time of assay $(\mathrm{min})$ and $k_{T h}$ is the Thomas' model constant ( $\mathrm{mL} / \mathrm{mg} \min )$.

The Yan's model (Eq. (6)) is more accurate than Thomas' model as it helps to overcome some of the drawbacks, such as predicting the initial concentration with respect to time zero, and describing the breakthrough curves in fixed-bed columns (Yan et al., 2001).

$\frac{C}{C_{0}}=1-\frac{1}{1+\left({\frac{\left.C_{0}\right)^{t} t}{10000_{0} m}}^{a}\right.}$

where $a$ is the Yan's model constant.

The Yoon-Nelson's model (Eq. (7)) doesn't require neither detailed data about characteristics of adsorbate, the type of adsorbent, nor physical proportions of the adsorption bed (Yoon and Nelson, 1984).

$\frac{C}{C_{0}}=\frac{\operatorname{Exp}[k(t-\tau)]}{1+\operatorname{Exp}[k(t-\tau)]}$

Being $k$ the Yoon-Nelson's model constant $\left(\mathrm{min}^{-1}\right)$ and $\tau$ the time (min) required for $50 \%$ adsorbate breakthrough.

\subsection{Determination of fluoxetine concentration}

The concentration of FLX was measured by a high-performance liquid chromatography with fluorescence detection (HPLC-FLD), using a Shimadzu LC Prominence system (Shimadzu Corporation, Kyoto, Japan) equipped with a LC-20AB pump, a DGU-20A5 degasser, a SIL20A autosampler, a CTO-20AC column oven, and a RF-10A-XL fluorescence detector (FLD). The control of the chromatographic system and the acquisition and processing of chromatographic data were made using LC solution version 1.25 SP2 software. The separation was achieved with a Luna $\mathrm{C}_{18}$ column $(150 \mathrm{~mm} \times 4.6 \mathrm{~mm}, 5 \mu \mathrm{m})$ from Phenomenex, using the method described by Silva et al. (2019). FLX quantification was carried out using external calibration. For that, different concentrations (ranging from 2.5 to $20,000 \mu \mathrm{g} / \mathrm{L}$ ) were prepared in water from the respective stock solution $(1000 \mathrm{mg} / \mathrm{L}$ prepared in methanol), and FLX limits of detection and quantification were 386 and $1285 \mu \mathrm{g} / \mathrm{L}$, respectively. The concentration of FLX found in each sample, resulting from triplicate injections, was expressed as $\mathrm{mg} / \mathrm{L}$.

As in many studies in literature, this study was made in concentrations higher than environmental levels in order to study the process with more accuracy and precision, since it is known that adsorption is a quite efficient process even at low concentration levels (Mohanty et al., 2006).

\section{Results and discussion}

\subsection{Preliminary adsorption assays}

In this study, twelve different biochars prepared from forest and agri-food wastes were tested to evaluate their removal efficiency for the pharmaceutical compound FLX from aqueous solutions. Concerning the results obtained in the preliminary batch assays, it was found that the produced biochars reached a pharmaceutical removal ranging from $36 \%$ for pine to $100 \%$ for eucalyptus residues, respectively. These differences are related with the different physical (e.g. granulometry, specific surface area and pore size distribution) and chemical (e.g. type and abundance of functional groups present in the surface of the adsorbent) properties of the prepared biochars. These preliminary data enabled to select the produced biochars with the highest removal capacity, namely hollow tree, quince, eucalyptus, walnut tree and vine, in order to be subsequently fully characterized.

\subsection{Biochar characterization}

A detailed physico-chemical characterization was carried out for each selected biochar in order to understand their adsorption behavior.

Proximate and elemental analyses, and mineral composition of biochars are reported in Table 1 . A relevant characteristic shown by these biochars was the high fixed carbon content. The prepared biochars are mainly composed by carbon (higher than $79 \% \mathrm{w} / \mathrm{w}$ for all biochars) and oxygen, with small amounts of hydrogen (less than $2.12 \%$ $\mathrm{w} / \mathrm{w}$ ) and nitrogen (less than $0.93 \% \mathrm{w} / \mathrm{w}$ ). Ash content was low for all the biochar samples (less than $6 \% \mathrm{w} / \mathrm{w}$ ). Sulfur is below $0.01 \% \mathrm{w} / \mathrm{w}$ in all the produced biochars. Regarding the mineral composition, Ca was the major element in all produced biochars, except for quince and vine, which presented higher levels of $\mathrm{K}$. On the other hand, the lowest element content in biochars was found to be $\mathrm{Zn}$, except for walnut tree which presented lower levels of Ni. The total mineral content of the analyzed chemical elements from vine biochar was 3.4-fold higher, if compared to the eucalyptus biochar, which presented the smallest mineral content (10655 vs $36191 \mathrm{mg} / \mathrm{kg}$, in dry basis, for eucalyptus and vine, respectively). Eucalyptus biochar presents the lowest content of volatile matter, which may indicate that pyrolysis was able to convert more organic matter of this material, when compared with the other biochars, contributing to an increase of its porosity and specific surface area.

Table 2 summarizes the results of textural characterization, namely the specific surface area and pore volume, which influence the adsorptive capacity of the produced biochars, and $\mathrm{pH}_{\mathrm{pzc}}$. It is clear that eucalyptus biochar has the larger BET surface area and pore volume. The granulometric results obtained allow to verify that, although sieved to $75 \mu \mathrm{m}$, the materials still have particles with higher diameters, which may indicate elongated geometries. Table 2 reports the particle size 
Table 1

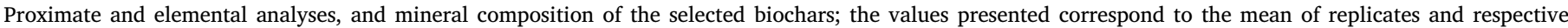
standard deviation, except for elemental analysis.

\begin{tabular}{|c|c|c|c|c|c|}
\hline Biochar source & Eucalyptus & Hollow tree & Quince & Vine & Walnut tree \\
\hline \multicolumn{6}{|c|}{ Proximate analysis (\% ar $\left.{ }^{a}\right)$} \\
\hline Moisture & $9.67 \pm 0.10$ & $5.40 \pm 0.34$ & $6.20 \pm 0.18$ & $4.32 \pm 0.00$ & $4.93 \pm 0.04$ \\
\hline Volatile matter & $7.76 \pm 0.15$ & $18.2 \pm 0.3$ & $15.8 \pm 0.6$ & $16.9 \pm 0.2$ & $15.9 \pm 0.4$ \\
\hline Ashes & $1.67 \pm 0.09$ & $4.55 \pm 0.22$ & $5.05 \pm 0.39$ & $5.90 \pm 0.19$ & $4.87 \pm 0.46$ \\
\hline Fixed carbon ${ }^{\mathrm{b}}$ & $80.90 \pm 0.01$ & $71.85 \pm 0.40$ & $72.95 \pm 0.30$ & $72.88 \pm 0.01$ & $74.30 \pm 0.01$ \\
\hline \multicolumn{6}{|c|}{ Elemental analysis $\left(\% d b^{c}\right)$} \\
\hline $\mathrm{C}$ & 83.61 & 79.47 & 79.92 & 80.31 & 81.58 \\
\hline $\mathrm{O}^{\mathrm{d}}$ & 12.75 & 13.79 & 12.86 & 11.13 & 10.79 \\
\hline $\mathrm{H}$ & 1.56 & 1.88 & 1.55 & 1.73 & 2.12 \\
\hline $\mathrm{N}$ & 0.41 & 0.31 & 0.62 & 0.93 & 0.64 \\
\hline S & $<0.01$ & $<0.01$ & $<0.01$ & $<0.01$ & $<0.01$ \\
\hline \multicolumn{6}{|c|}{ Mineral analysis $\left(\mathrm{mg} / \mathrm{kg} d b^{d}\right)$} \\
\hline $\mathrm{Ca}$ & $3349 \pm 107$ & $19181 \pm 1794$ & $9947 \pm 241$ & $13236 \pm 252$ & $14710 \pm 107$ \\
\hline $\mathrm{K}$ & $1944 \pm 20$ & $10599 \pm 831$ & $14437 \pm 522$ & $18469 \pm 480$ & $8922 \pm 196$ \\
\hline $\mathrm{Na}$ & $1882 \pm 43$ & $209 \pm 18$ & $278 \pm 8$ & $376 \pm 35$ & $1425 \pm 111$ \\
\hline $\mathrm{Fe}$ & $1407 \pm 13$ & $305 \pm 17$ & $1296 \pm 15$ & $748 \pm 37$ & $313 \pm 11$ \\
\hline $\mathrm{Mg}$ & $1279 \pm 10$ & $2462 \pm 211$ & $2792 \pm 18$ & $2587 \pm 130$ & $2158 \pm 29$ \\
\hline $\mathrm{Al}$ & $367 \pm 21$ & $127 \pm 1$ & $184 \pm 3$ & $333 \pm 1$ & $357 \pm 43$ \\
\hline $\mathrm{Cr}$ & $208 \pm 2$ & $56 \pm 18$ & $265 \pm 2$ & $158 \pm 13$ & $64 \pm 15$ \\
\hline $\mathrm{Ni}$ & $125 \pm 5$ & $43 \pm 3$ & $149 \pm 0$ & $114 \pm 34$ & $54 \pm 3$ \\
\hline $\mathrm{Cu}$ & $87 \pm 1$ & $39 \pm 5$ & $101 \pm 2$ & $92 \pm 5$ & $87 \pm 5$ \\
\hline $\mathrm{Zn}$ & $7.49 \pm 0.74$ & $7.91 \pm 0.32$ & $68.4 \pm 0.3$ & $77.6 \pm 0.3$ & $68.2 \pm 1.3$ \\
\hline
\end{tabular}

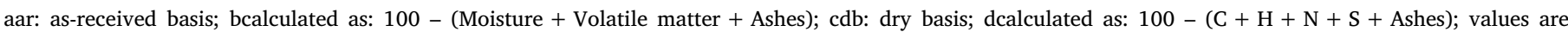
means \pm standard deviations.

Table 2

Textural characteristics and $\mathrm{pH}_{\mathrm{pzc}}$ of the selected biochars.

\begin{tabular}{lllllll}
\hline Biochar source & $\begin{array}{l}\text { Surface } \\
\text { area } \\
\left(\mathrm{m}^{2} / \mathrm{g}\right)\end{array}$ & $\begin{array}{l}\text { Total } \\
\text { pore } \\
\text { volume } \\
\end{array}$ & & \multicolumn{2}{l}{ Particle size distribution $(\mu \mathrm{m})$} & $\mathrm{pH}_{\mathrm{pzc}}$ \\
\cline { 5 - 7 } & & $\mathrm{cm} / \mathrm{g})$ & & $\mathrm{D} 50$ & $\mathrm{D} 90$ & \\
\hline Eucalyptus & 335 & 0.17 & 3.87 & 13.54 & 53.96 & 9.75 \\
Hollow tree & 207 & 0.10 & 4.30 & 19.25 & 59.53 & 9.59 \\
Quince & 230 & 0.12 & 4.34 & 27.26 & 84.93 & 9.75 \\
Vine & 62 & 0.03 & 3.72 & 14.18 & 72.63 & 9.61 \\
Walnut tree & 219 & 0.11 & 3.79 & 15.60 & 66.06 & 9.85 \\
\hline
\end{tabular}

distribution for the selected biochars, and it can be observed that $50 \%$ of particles have a diameter lower than $27 \mu \mathrm{m}$, which will influence the FLX adsorption.

The obtained FTIR spectra presented a very similar pattern for all the biochars. Peaks appearing at $3440 \mathrm{~cm}^{-1}$ attributed to the $\mathrm{O}-\mathrm{H}$ stretching vibration (Coates, 2006; Qian et al., 2013) were identified, which in this case is related to the water present in samples, since they were not dried before FTIR analysis. The minor bands at $2921 \mathrm{~cm}^{-1}$ and $2853 \mathrm{~cm}^{-1}$, more significant for vine, correspond to the stretching of $\mathrm{C}-\mathrm{H}$ for aliphatic (alkane/alkyl) groups; the bands at $1633 \mathrm{~cm}^{-1}$ and $1385 \mathrm{~cm}^{-1}$ can be attributed to $\mathrm{C}=\mathrm{C}$ and to methyl group $\left(-\mathrm{CH}_{3}\right)$ stretching vibration, respectively (Coates, 2006; Qian et al., 2013). The bands at $1454 \mathrm{~cm}^{-1}$ and at $877 \mathrm{~cm}^{-1}$, more evident in hollow tree, can be assigned to aromatic ring stretch $(\mathrm{C}=\mathrm{C}-\mathrm{C})$ and to aromatic $\mathrm{C}-\mathrm{H}$ outof-plane bend.

Thermogravimetric studies were carried out for the selected biochars to evaluate their thermal stability. The obtained results reveal that all samples are quite stable up to $600{ }^{\circ} \mathrm{C}$, presenting mass losses lower than $10 \% \mathrm{w} / \mathrm{w}$, which was expected as pyrolysis occurred at $500^{\circ} \mathrm{C}$. Above this temperature, eucalyptus biochar presented a rather insignificant degradation up to $850^{\circ} \mathrm{C}$ with a total mass loss of around $8 \% \mathrm{w} / \mathrm{w}$. Hollow tree biochar presented the higher mass loss at $850{ }^{\circ} \mathrm{C}$ $(14 \% \mathrm{w} / \mathrm{w})$. These results indicated that these biochar samples can be thermally regenerated/activated without a significant mass loss.

The $\mathrm{pH}_{\mathrm{pzc}}$ is a very important parameter characterizing the acidbase behavior of the solids at which the net surface charge of the adsorbent becomes electrically neutral. The adsorbent surface tends to be negatively charged at $\mathrm{pH}>\mathrm{pH}_{\mathrm{pzc}}$ and tends to attract cations, while at $\mathrm{pH}<\mathrm{pH}_{\mathrm{pzc}}$ tends to be positively charged attracting anions from the solution (Sayğılı et al., 2015). The experimental results of $\mathrm{pH}_{\mathrm{pzc}}$ (Table 2) demonstrate the basic character of the produced biochars $\left(\mathrm{pH}_{\mathrm{pzc}}>9\right.$ for all biochars). These results agree with the overall literature about biochars that typically indicate basic properties (Ahmad et al., 2014; Bis et al., 2018; El-Naggar et al., 2019) for this type of materials.

\subsection{Kinetic assays}

The effect of contact time on adsorption was determined in order to characterize the equilibrium adsorption time for the five selected biochars. This assay gives information about the rate at which the retention takes place and the minimum contact time required to reach the equilibrium (Sardella et al., 2015). As it can be seen from Fig. 1A, the FLX removal is very fast in the first minute of the adsorption assay. After the first fifteen minutes of the assay, the equilibrium was achieved for all the studied adsorbents. Thus, the contact time was fixed at this value for the following batch adsorption experiments. Moreover, the performed kinetic studies (Fig. 1A) show that the amount of FLX adsorbed per gram of adsorbent is very similar for all the tested materials except for eucalyptus, which presents a much higher FLX adsorption capacity (5.74 vs $2.79 \mathrm{mg} / \mathrm{g}$ for eucalyptus and quince, respectively). This difference could be related with the fact that this material presents the highest total volume of pores and the highest specific surface area, at least $100 \mathrm{~m}^{2} / \mathrm{g}$ higher than the other studied biochars, therefore more sites are available for the FLX adsorption.

Additionally, the evolution of $\mathrm{pH}$ during the contact time was also measured (Fig. 1B). The $\mathrm{pH}$ of the original solution of FLX (before adding the biochars) was 6.5. During the kinetic assays, the $\mathrm{pH}$ variation (Fig. 1B) was not significant and converged to the $\mathrm{pH}_{\mathrm{pzc}}$ values for all biochars, except for eucalyptus biochar, which showed a decrease from 9.30 to 7.40 during the $60 \mathrm{~min}$ of experiment. It suggests that it may occur an interaction biochar/adsorbate that originates neutral or moderately acid products. 


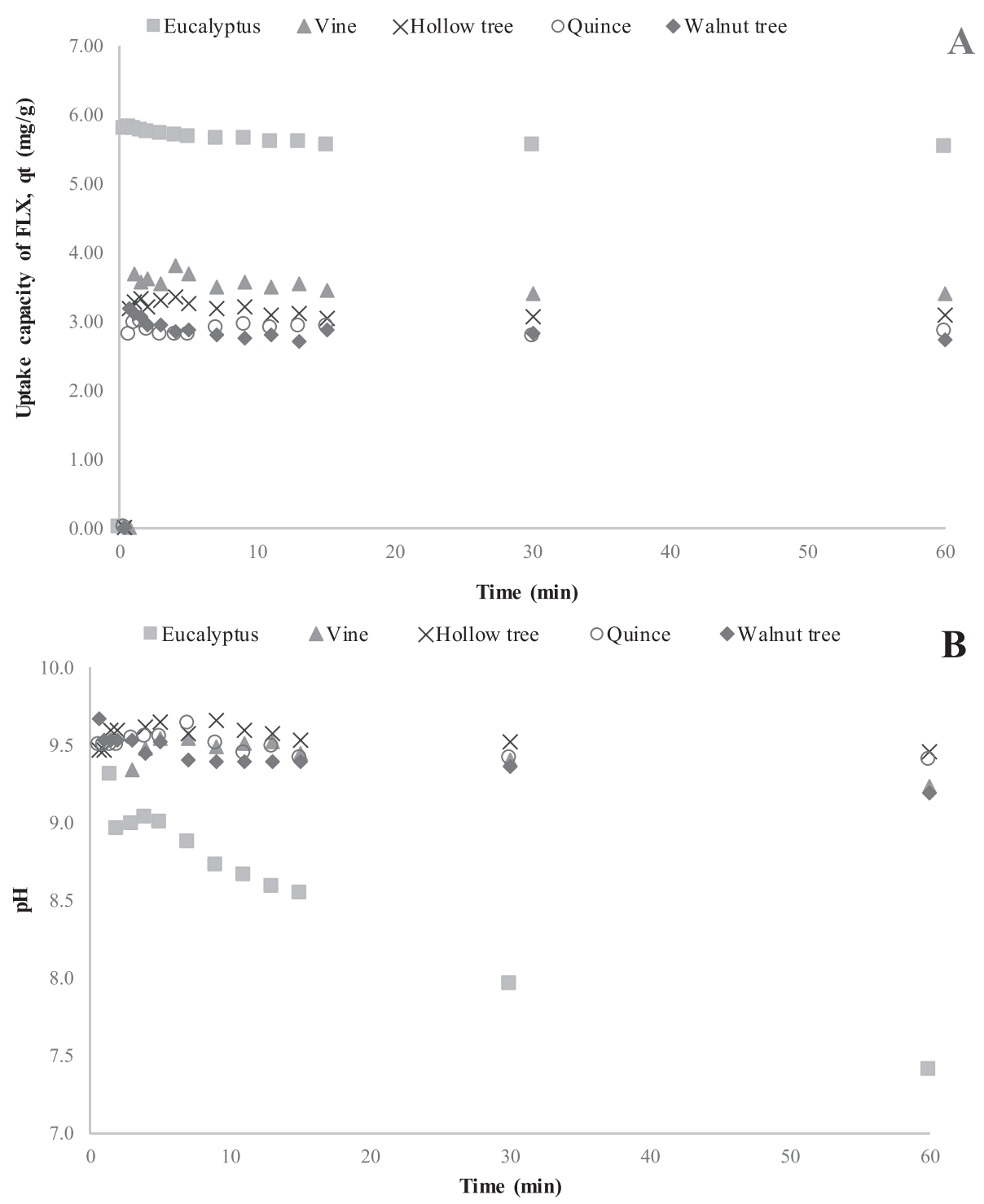

Fig. 1. Uptake capacity of FLX (A) and pH evolution (B) during kinetic experiments for the five selected biochars.

\section{4. $p H$ studies}

The effect of $\mathrm{pH}$ on the removal of FLX was investigated only for the three most promising biochars, namely eucalyptus, hollow tree and vine, in the range between 4.0 and 7.0. The selection was made considering the results obtained in the preliminary adsorption assays, as well as the information from the kinetic studies (Fig. 1A), which showed that the highest uptake capacity of fluoxetine was obtained for eucalyptus, hollow tree and vine. Regarding the $\mathrm{pH}$ range, it was selected considering that in wastewater treatment plants the $\mathrm{pH}$ values allowed by biological treatments and permitted for discharge are near neutral. Despite the efforts to perform $\mathrm{pH}$ studies at values above the range tested (7.0-9.0), it was impossible to maintain the FLX solution $\mathrm{pH}$ value (blank) in the adjusted initial $\mathrm{pH}$ after $120 \mathrm{~min}$. In fact, as it can be seen from Fig. 2A analysis, for all blank assays, a decrease was noticed during the experiment, which was higher for higher initial $\mathrm{pH}$ values, namely for 7.0 a decrease of 0.9 units in the blank test was observed, except for $\mathrm{pH} 5.0$ for which no significant variation was observed. The initial pH of the systems biochar/FLX in aqueous solution was adjusted to 4, 5, 6 or 7, as in the blank tests, but after 1 min changes were already noticed (Fig. 2A) and final $\mathrm{pH}$ values (at $120 \mathrm{~min}$ ) converged to $6.50-6.78$ for eucalyptus and to $7.75-8.72$ for hollow tree and vine, regardless of the initial $\mathrm{pH}$. Although it was expected an increase of the $\mathrm{pH}$ towards the $\mathrm{pH}_{\mathrm{pzc}}$ during the experiment, this was only observed in the first minutes (Fig. 2A, measurement at $1 \mathrm{~min}$ ) and then a decrease was observed, which might be attributed to the behavior of FLX in aqueous solution as detected in the blank assays. This decrease was more significant in the eucalyptus biochar, as verified in the kinetic experiment probably due to its higher specific surface area (Table 2) that favors the interaction of the biochar surface and FLX.

Fig. $2 \mathrm{~B}$ presents the effect of initial $\mathrm{pH}$, ranging from 4.0 to 7.0 , on the amount of FLX adsorbed per gram of adsorbent $\left(q_{e}, \mathrm{mg} / \mathrm{g}\right)$. In the case of hollow tree and vine, it can be observed that the amount of FLX adsorbed was not influenced by $\mathrm{pH}$. On the contrary, for eucalyptus, the FLX adsorption capacity increased at least 5.9 times, between $\mathrm{pH} 4.0$ and 7.0, reaching a maximum value of $8.23 \mathrm{mg} / \mathrm{g}$ at an initial $\mathrm{pH}$ of 7.0. The $\mathrm{pH}$ is one of the most important factors on the adsorption process, affecting not only the solvent chemistry but also the surface binding sites of the adsorbent (Demiral and Güngör, 2016; Sardella et al., 2015; Turk Sekulić et al., 2018), which could explain the obtained differences for the FLX adsorption. In fact, the $\mathrm{pH}$ solution can control the electrostatic interactions between the adsorbent and the adsorbate (Özçimen and Ersoy-Meriçboyu, 2009). The differences observed between FLX adsorption at different $\mathrm{pH}$ values could be related with the electrostatic interaction between the net surface charge of the adsorbent and the electric charge of FLX molecules. Once the pKa of FLX is 


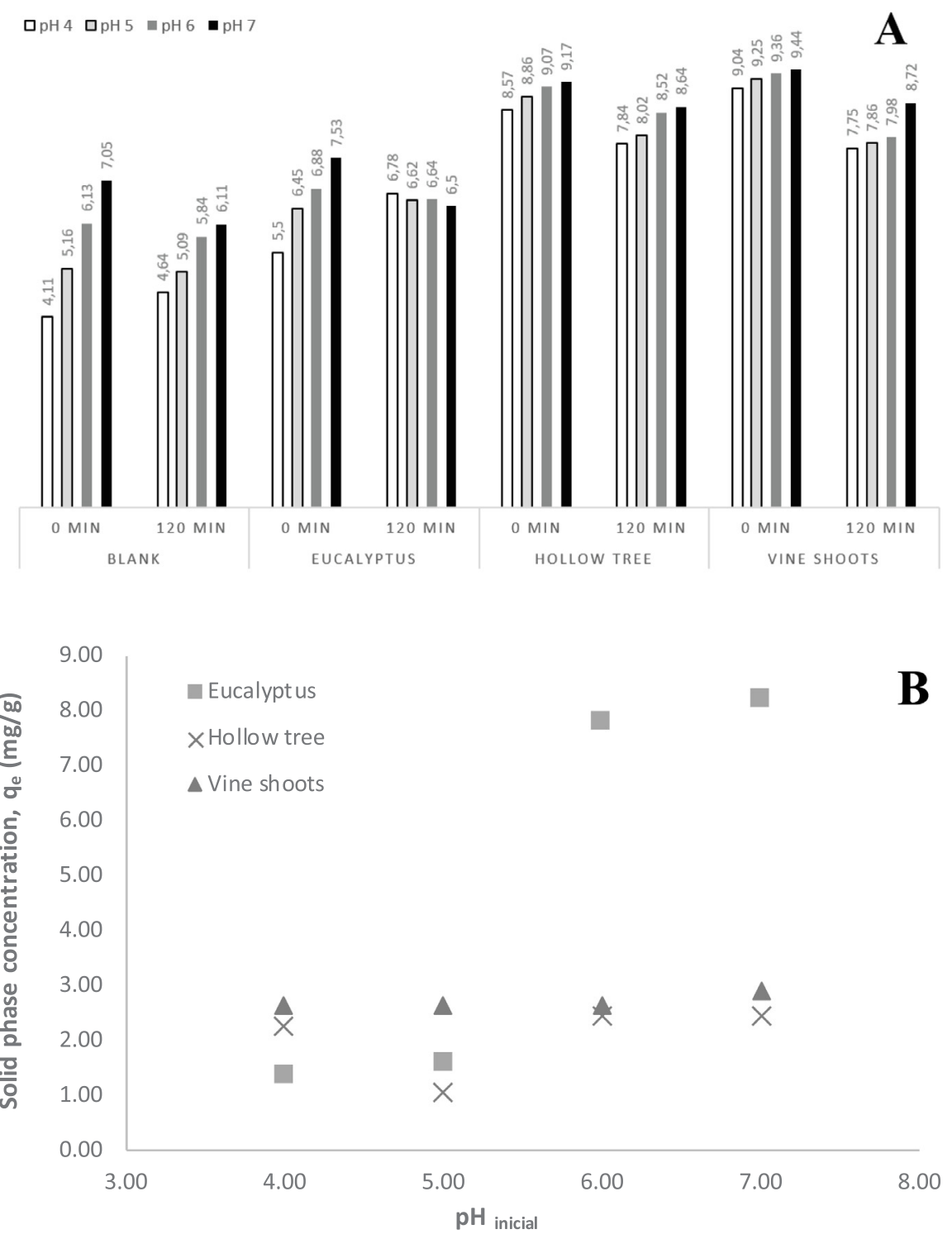

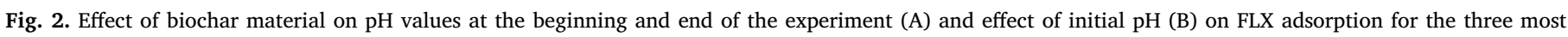
promising adsorbents, namely eucalyptus, hollow tree and vine.

9.8, for all $\mathrm{pH}$ values studied ( $\mathrm{pH}<\mathrm{pKa}$ ), the molecules were mainly protonated, increasing the net positive charge with the decrease of $\mathrm{pH}$ (Silva et al., 2019). Regarding the biochars tested, all the $\mathrm{pH}_{\mathrm{pzc}}$ values were above 9.59 (Table 2), which means that in the $\mathrm{pH}$ range of the experiments (5.5-9.5) the biochars should be positively charged $\left(\mathrm{pH}<\mathrm{pH}_{\mathrm{pzc}}\right)$ contributing to the electrostatic repulsion between the adsorbent and the adsorbate. This repulsion increases as the $\mathrm{pH}$ decreases, since 2 units below the pKa FLX should be positively charged and the same occurs for biochars 2 units below the $\mathrm{pH}_{\mathrm{pzc}}$ (Silva et al., 2019). The maximum electrostatic repulsion should occur below $\mathrm{pH} 7$, but this was not the main factor that influenced the adsorption, since the best results were obtained for eucalyptus biochar near this $\mathrm{pH}$ value.

Other factors should also be considered, namely the direct interaction of the pharmaceutical with the surface functional groups on the biochar surface, to explain the increase of adsorption capacity of eucalyptus biochar at initial $\mathrm{pH}$ in the range 6.0-7.0. From the functional groups identified in the FTIR of this biochar, there are no groups with marked acidic or alkaline characteristics that could be involved in the adsorption process. However, some functional groups on the biochar surface become deprotonated when $\mathrm{pH}$ increases and therefore negatively charged, thus favoring adsorption of the pharmaceutical compound (Silva et al., 2019).

Additionally, another assay was also carried out to evaluate the $\mathrm{pH}$ influence, where the $\mathrm{pH}$ adjustment was made after leaching of the biochars and FLX solution was added just before the experiment. In this case, no variations of $\mathrm{pH}$ values were noticed during the experiment: the initial and final $\mathrm{pH}$ values were, respectively, 6.96 and 7.09 for eucalyptus, 7.76 and 7.75 for hollow tree and 7.60 and 7.68 for vine. Concerning the amount of FLX adsorbed, no considerable improvements were observed compared to the values obtained in the abovementioned pH study $(7.21,2.66$ and $3.01 \mathrm{mg} / \mathrm{g}$ for eucalyptus, hollow tree and vine biochars, respectively).

\subsection{Adsorption isotherms}

Adsorption isotherms are very important to understand how the molecules or ions of FLX interact with surface sites of the biochars selected. Therefore, the correlation of experimental data using either a theoretical or empirical equation is essential for the adsorption 

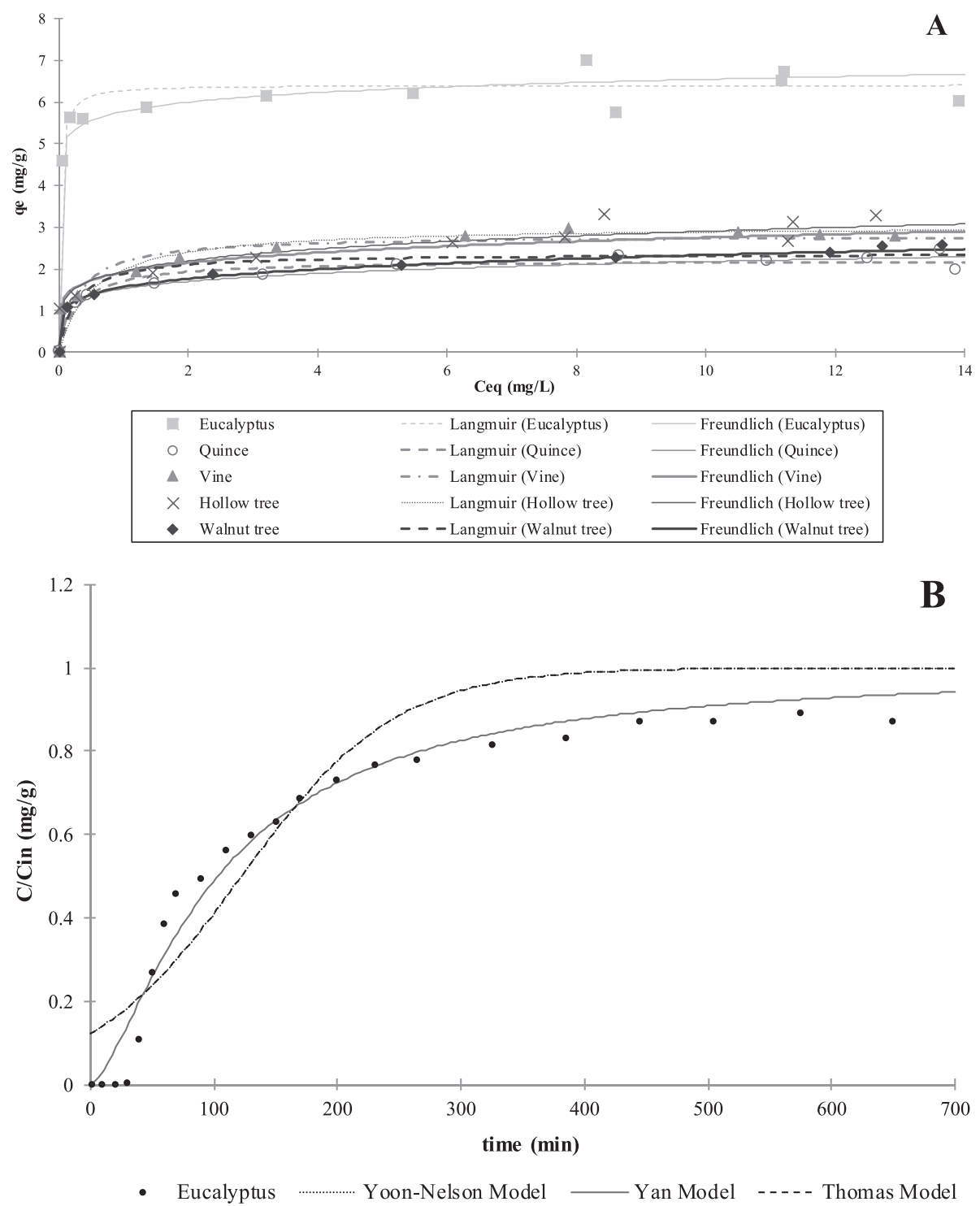

Fig. 3. Experimental results and fitted models for equilibrium batch (A) and continuous (packed column) studies (B).

interpretation and prediction of its extent (Demiral and Güngör, 2016).

The results of the equilibrium studies for the five selected biochars together with the fitted models are presented in Fig. 3A. The estimated models' parameters, correlation coefficients and RMSE are gathered in Table 3. A comparative analysis of the statistical parameters shows that the Freundlich's model (Table 3), which presented the smallest values of RMSE and the greatest values of $\mathrm{R}^{2}$, was the best fit although Langmuir model could also fit the equilibrium results. These results suggest that the biochars tested have heterogeneous adsorption sites, which are favorable for adsorption phenomenon (Cobas et al., 2016;
Turk Sekulić et al., 2018). Additionally, the obtained results led to the conclusion that eucalyptus is the most efficient FLX adsorbent, as the maximum Langmuir monolayer adsorption capacity $\left(Q_{m}\right)$ is at least 2fold higher than for the other biochars. On the other hand, the biochar walnut tree was characterized by the lowest adsorption capacity $(2.30 \mathrm{mg} / \mathrm{g})$. Concerning the Freundlich's parameters, $K_{F}$, which represents the tendency of the adsorbent to adsorb, was found to decrease in the sequence eucalyptus $>$ hollow tree $>$ vine $>$ walnut tree $>$ quince, which agrees with the results revealed by Langmuir's model. The parameter $n$, which characterizes the ability of the FLX to be

Table 3

Langmuir and Freundlich isotherm parameters for fluoxetine adsorption.

\begin{tabular}{|c|c|c|c|c|c|c|c|c|}
\hline \multirow[t]{2}{*}{ Biochar source } & \multicolumn{4}{|c|}{ Langmuir model } & \multicolumn{4}{|l|}{ Freundlich model } \\
\hline & $\mathrm{K}_{\mathrm{L}}(\mathrm{L} / \mathrm{mg})$ & $\mathrm{Q}_{\mathrm{m}}(\mathrm{mg} / \mathrm{g})$ & $\mathrm{R}^{2}$ & RMSE & $\mathrm{K}_{\mathrm{F}}\left(\left[(\mathrm{mg} / \mathrm{g})(\mathrm{L} / \mathrm{mg})^{1 / \mathrm{n}}\right)\right]$ & $n$ & $\mathrm{R}^{2}$ & RMSE \\
\hline Eucalyptus & 45.37 & 6.41 & 0.93 & 0.51 & 5.77 & 18.29 & 0.95 & 0.44 \\
\hline Hollow tree & 1.87 & 3.04 & 0.88 & 0.43 & 1.95 & 5.79 & 0.94 & 0.25 \\
\hline Quince & 3.41 & 2.21 & 0.95 & 0.17 & 1.53 & 6.53 & 0.96 & 0.14 \\
\hline Vine & 3.38 & 2.80 & 0.93 & 0.29 & 1.93 & 6.47 & 0.96 & 0.19 \\
\hline Walnut tree & 3.85 & 2.37 & 0.94 & 0.22 & 1.56 & 5.76 & 0.99 & 0.07 \\
\hline
\end{tabular}


Table 4

Parameters for the Yoon-Nelson, Thomas and Yan models for the adsorption of FLX onto eucalyptus biochar in a fixed-bed column.

\begin{tabular}{lll}
\hline Model & Parameters & Eucalyptus biochar \\
\hline Yoon-Nelson & $\mathrm{k}_{\mathrm{YN}}\left(\mathrm{min}^{-1}\right)$ & 0.016 \\
& $\tau_{\mathrm{YN}}(\mathrm{min})$ & 122.081 \\
& $\mathrm{RMSE}$ & 0.124 \\
& $\mathrm{R}^{2}$ & 0.900 \\
Thomas & $\mathrm{k}_{\mathrm{TH}}$ & 0.629 \\
& $(\mathrm{~mL} /(\mathrm{mg} \min ))$ & \\
& $\mathrm{q}_{\mathrm{TH}}(\mathrm{mg} / \mathrm{g})$ & 1.57 \\
$\mathrm{RMSE}$ & 0.124 \\
& $\mathrm{R}^{2}$ & 0.900 \\
Yan & $\mathrm{a}_{\mathrm{Ya}}$ & 1.454 \\
& $\mathrm{q}_{\mathrm{Ya}}(\mathrm{mg} / \mathrm{g})$ & 1.322 \\
$\mathrm{RMSE}$ & 0.056 \\
& $\mathrm{R}^{2}$ & 0.974 \\
\hline
\end{tabular}

adsorbed, presented values higher than 1 , indicating favorable adsorption of FLX for all the investigated biochars. These results confirm the ones obtained with the kinetic study, in which eucalyptus biochar performed better. The best textural properties presented by this material (Table 2) played the major role on FLX removal.

Several studies have been conducted using different types of adsorbents for FLX removal (Jaria et al., 2015; Silva et al., 2019), although only one study was found regarding the use of biochars prepared from fishbones (Piccirillo et al., 2017). In the present study the adsorption capacity of the majority biochars tested was found to be lower than the adsorption capacity reported by Piccirillo et al. (2017). These authors employed higher pyrolysis temperatures (ranging from 600 to $1000^{\circ} \mathrm{C}$ ) and the highest adsorption capacity was obtained at $1000{ }^{\circ} \mathrm{C}(55.87 \mathrm{mg} / \mathrm{g})$. Comparing the obtained $Q_{m}$ values for similar pyrolysis temperatures, in the present study it was obtained a maximum adsorption capacity of $6.41 \mathrm{mg} / \mathrm{g}$ for eucalyptus at $500^{\circ} \mathrm{C}$, which is 2.5 times higher than the value obtained with fishbones biochar at $600{ }^{\circ} \mathrm{C}$ $(2.52 \mathrm{mg} / \mathrm{g})$. Despite of the lower adsorption capacity when compared to commercially available adsorbents (Jaria et al., 2015; Silva et al., 2019), this study demonstrated that the investigated biochars could be considered as promising alternative low-cost materials for the removal of FLX from aqueous solutions.

\subsection{Column adsorption assay}

To evaluate the behaviour of the most promising biochar, produced from eucalyptus biomass wastes, in a continuous adsorption process, experimental assays were performed using a fixed-bed column. To the best of authors' knowledge, this is the first continuous study in packed column using biochars for the adsorption of FLX.

In this experiment, FLX reached the saturation after approximately $10 \mathrm{~h}$ (Fig. 3B). Three models, namely Yoon-Nelson's, Thomas's and Yan's were selected to be fitted to the experimental, which are represented in Fig. 3B. The parameters, the correlation coefficients as well as RMSE obtained for each model were determined (Table 4).

The Thomas model is usually employed to estimate the extent and rate constant of sorption and assumes that the external and internal mass transfer resistances are not limiting steps (Martínez-Lladó et al., 2011). The Yoon and Nelson (1984) model was only used as a descriptive model. Yoon-Nelson's and Thomas's models presented the same parameters and therefore the same fitted curve. Yan's model can overcome the Thomas model deficiency in predicting the concentration at initial times and provide a more accurate description of the different parts of the breakthrough curve (Yan and Viraraghavan, 2001; Yan et al., 2001), what justifies its better performance (higher correlation coefficient, 0.974, and lower RMSE, 0.056). The adsorption capacity predicted by this model for eucalyptus in the column $(1.3 \mathrm{mg} / \mathrm{g})$ was 5 times lower than the predicted by the Langmuir isotherm $(6.4 \mathrm{mg} / \mathrm{g})$. The amount of FLX adsorbed during the column experiment (estimated by numerical integration of the area above the breakthrough curve) reached the level of $4.3 \mathrm{mg} / \mathrm{g}$, which is in accordance with the value predicted by the Langmuir isotherm considering that the estimation of the capacity based in experimental values was underestimated (the saturation of the adsorbent was not achieved, only $89 \%$ was reached). The breakthrough for $50 \%$ removal can be estimated as $90 \mathrm{~min}$ for eucalyptus biochar.

\section{Conclusions}

The present study demonstrated that biochars prepared from different forest/agri-food wastes could be used as effective adsorbents for FLX removal, with adsorption capacities ranging from 2.21 to $6.41 \mathrm{mg}$ / $\mathrm{g}$ (Langmuir model) for the five selected biochars, eucalyptus biochar presented the highest adsorption capacity, followed by hollow tree, vine, walnut tree and quince. Adsorption kinetics was fast (less than $15 \mathrm{~min}$ ). Additionally, column adsorption assays demonstrated good performance of this low-cost adsorbent in continuous mode, showing that eucalyptus biochar can be effectively used as renewable alternative for FLX removal. Future studies on life cycle assessment and cost analysis will be performed.

\section{Acknowledgements}

Manuela M. Moreira is grateful for the financial support financed by national funds through FCT - Fundação para a Ciência e a Tecnologia, I.P., within the scope of the project CEECIND/02702/2017 and to REQUIMTE/LAQV. The authors are also grateful for the financial support from FCT/MCTES through national funds (UID/QUI/50006/2019), project PTDC/ASP-PES/29547/2017 (POCI-01-0145-FEDER-29547) by FUNCAP and FCT/MCTES with national funds and co-funded by FEDER and to the projects "PTDC/BII-BIO/30884/2017" and WaterJPI/0007/ 2016 financed by ERA-NET Cofund Water Works 2015. The supply of the vineyard prunings is acknowledged to Sogrape, S.A. and the biochar production to Ibero Massa Florestal.

\section{Appendix A. Supplementary data}

Supplementary data to this article can be found online at https:// doi.org/10.1016/j.biortech.2019.121973.

\section{References}

Ahmad, M., Rajapaksha, A.U., Lim, J.E., Zhang, M., Bolan, N., Mohan, D., Vithanage, M., Lee, S.S., Ok, Y.S., 2014. Biochar as a sorbent for contaminant management in soil and water: a review. Chemosphere 99, 19-33.

Ahmed, M.B., Zhou, J.L., Ngo, H.H., Guo, W., Chen, M., 2016. Progress in the preparation and application of modified biochar for improved contaminant removal from water and wastewater. Bioresour. Technol. 214, 836-851.

Biel-Maeso, M., Corada-Fernandez, C., Lara-Martin, P.A., 2018. Monitoring the occurrence of pharmaceuticals in soils irrigated with reclaimed wastewater. Environ. Pollut. 235, 312-321.

Bis, Z., Kobyłecki, R., Ścisłowska, M., Zarzycki, R., 2018. Biochar - Potential tool to combat climate change and drought. Ecohydrol. Hydrobiol. 18, 441-453.

Carabineiro, S.A.C., Thavorn-amornsri, T., Pereira, M.F.R., Serp, P., Figueiredo, J.L., 2012. Comparison between activated carbon, carbon xerogel and carbon nanotubes for the adsorption of the antibiotic ciprofloxacin. Catal. Today 186, 29-34.

Coates, J., 2006. Interpretation of Infrared Spectra, A Practical Approach, in: e.R.A.M.a. M.L. McKelvy (Ed.), Encyclopedia of Analytical Chemistry.

Cobas, M., Meijide, J., Sanromán, M.A., Pazos, M., 2016. Chestnut shells to mitigate pesticide contamination. J. Taiwan Inst. Chem. E 61, 166-173.

Demiral, H., Güngör, C., 2016. Adsorption of copper(II) from aqueous solutions on activated carbon prepared from grape bagasse. J. Cleaner Prod. 124, 103-113.

El-Naggar, A., Lee, S.S., Rinklebe, J., Farooq, M., Song, H., Sarmah, A.K., Zimmerman, A.R., Ahmad, M., Shaheen, S.M., Ok, Y.S., 2019. Biochar application to low fertility soils: a review of current status, and future prospects. Geoderma 337, 536-554.

European, Standard, 2011. EN15290:2011 - Solid biofuels - Determination of major elements - Al, Ca, Fe, Mg, P, K, Si, Na and Ti, European Committee for Standardization, Brussels.

Freundlich, H., 1907. Über die adsorption in Lösungen. Z. Phys. Chem. 57U, 385. 
Fryda, L., Visser, R., 2015. Biochar for soil improvement: evaluation of biochar from gasification and slow pyrolysis. Agriculture 5, 1076-1115.

Jaria, G., Calisto, V., Gil, M.V., Otero, M., Esteves, V.I., 2015. Removal of fluoxetine from water by adsorbent materials produced from paper mill sludge. J. Colloid Interface Sci. $448,32-40$.

Laghari, M., Naidu, R., Xiao, B., Hu, Z., Mirjat, M.S., Hu, M., Kandhro, M.N., Chen, Z., Guo, D., Jogi, Q., Abudi, Z.N., Fazal, S., 2016. Recent developments in biochar as an effective tool for agricultural soil management: a review. J. Sci. Food Agric. 96, 4840-4849.

Langmuir, I., 1918. The adsorption of gases on plane surfaces of glass, mica and platinum. J. Am. Chem. Soc. 40, 1361-1403.

Lehmann, J., Rillig, M.C., Thies, J., Masiello, C.A., Hockaday, W.C., Crowley, D., 2011. Biochar effects on soil biota - A review. Soil Biol. Biochem. 43, 1812-1836.

Liao, F., Yang, L., Li, Q., Li, Y.-R., Yang, L.-T., Anas, M., Huang, D.-L., 2018. Characteristics and inorganic $\mathrm{N}$ holding ability of biochar derived from the pyrolysis of agricultural and forestal residues in the southern China. J. Anal. Appl. Pyrol. 134, 544-551.

Martínez-Lladó, X., Valderrama, C., Rovira, M., Martí, V., Giménez, J., de Pablo, J., 2011. Sorption and mobility of $\mathrm{Sb}(\mathrm{V})$ in calcareous soils of Catalonia (NE Spain): Batch and column experiments. Geoderma 160, 468-476.

Mohanty, K., Das, D., Biswas, M.N., 2006. Preparation and characterization of activated carbons from Sterculiaalata nutshell by chemical activation with zinc chloride to remove phenol from wastewater. Adsorption 12, 119-132.

Moreira, M.M., Barroso, M.F., Boeykens, A., Withouck, H., Morais, S., Delerue-Matos, C., 2017. Valorization of apple tree wood residues by polyphenols extraction: comparison between conventional and microwave-assisted extraction. Ind. Crops Prod. 104, 210-220.

Moreira, M.M., Barroso, M.F., Porto, J.V., Ramalhosa, M.J., Švarc-Gajić, J., Estevinho, L., Morais, S., Delerue-Matos, C., 2018. Potential of Portuguese vine shoot wastes as natural resources of bioactive compounds. Sci. Total Environ. 634, 831-842.

Oliveira, F.R., Patel, A.K., Jaisi, D.P., Adhikari, S., Lu, H., Khanal, S.K., 2017. Environmental application of biochar: current status and perspectives. Bioresour. Technol. 246, 110-122.

Özçimen, D., Ersoy-Meriçboyu, A., 2009. Removal of copper from aqueous solutions by adsorption onto chestnut shell and grapeseed activated carbons. J. Hazard. Mater. 168, 1118-1125.

Paíga, P., Correia, M., Fernandes, M.J., Silva, A., Carvalho, M., Vieira, J., Jorge, S., Silva, J.G., Freire, C., Delerue-Matos, C., 2019. Assessment of 83 pharmaceuticals in WWTP influent and effluent samples by UHPLC-MS/MS: hourly variation. Sci. Total Environ. 648, 582-600.

Piccirillo, C., Moreira, I.S., Novais, R.M., Fernandes, A.J.S., Pullar, R.C., Castro, P.M.L 2017. Biphasic apatite-carbon materials derived from pyrolysed fish bones for effective adsorption of persistent pollutants and heavy metals. J. Environ. Chem. Eng. 5, 4884-4894.

Qian, K., Kumar, A., Patil, K., Bellmer, D., Wang, D., Yuan, W., Huhnke, R.L., 2013. Effects of biomass feedstocks and gasification conditions on the physiochemical properties of char. Energies 6, 3972-3986.

Redshaw, C.H., Cooke, M.P., Talbot, H.M., McGrath, S., Rowland, S.J., 2008. Low biodegradability of fluoxetine $\mathrm{HCl}$, diazepam and their human metabolites in sewage sludge-amended soil. J. Soils Sediments 8, 217.

Rosales, E., Meijide, J., Pazos, M., Sanromán, M.A., 2017. Challenges and recent advances in biochar as low-cost biosorbent: from batch assays to continuous-flow systems. Bioresour. Technol. 246, 176-192.

Sardella, F., Gimenez, M., Navas, C., Morandi, C., Deiana, C., Sapag, K., 2015. Conversion of viticultural industry wastes into activated carbons for removal of lead and cadmium. J. Environ. Chem. Eng. 3, 253-260.

Sayğıll, H., Güzel, F., Önal, Y., 2015. Conversion of grape industrial processing waste to activated carbon sorbent and its performance in cationic and anionic dyes adsorption. J. Cleaner Prod. 93, 84-93.

Silva, L.J., Lino, C.M., Meisel, L.M., Pena, A., 2012. Selective serotonin re-uptake in hibitors (SSRIs) in the aquatic environment: an ecopharmacovigilance approach. Sci. Total Environ. 437, 185-195.

Silva, A., Santos, Lúcia H.M.L.M., Delerue-Matos, C., Figueiredo, S.A., 2014. Impact of excipients in the chronic toxicity of fluoxetine on the alga Chlorella vulgaris. Environ. Technol. 35, 3124-3129.

Silva, A., Martinho, S., Stawiński, W., Węgrzyn, A., Figueiredo, S., Santos, Lúcia H.M.L.M., Freitas, O., 2018. Application of vermiculite-derived sustainable adsorbents for removal of venlafaxine. Environ. Sci. Pollut. Res. 25, 17066-17076.

Silva, A., Stawiński, W., Romacho, J., Santos, Lúcia H.M.L.M., Figueiredo, S.A., Freitas, O.M., Delerue-Matos, C., 2019. Adsorption of Fluoxetine and Venlafaxine onto the Marine Seaweed Bifurcaria bifurcata. Environ. Eng. Sci. 1-10.

Thomas, H.C., 1944. Heterogeneous ion exchange in a flowing system. J. Am. Chem. Soc. 66, 1664-1666.

Tripathi, M., Sahu, J.N., Ganesan, P., 2016. Effect of process parameters on production of biochar from biomass waste through pyrolysis: a review. Renew. Sustain. Energy Rev. 55, 467-481.

Turk Sekulić, M., Pap, S., Stojanović, Z., Bošković, N., Radonić, J., Šolević Knudsen, T., 2018. Efficient removal of priority, hazardous priority and emerging pollutants with Prunus armeniaca functionalized biochar from aqueous wastes: experimental optimization and modeling. Sci. Total Environ. 613-614, 736-750.

Yan, G., Viraraghavan, T., Chen, M., 2001. A new model for heavy metal removal in a biosorption column. Adsorp. Sci. Technol. 19, 25-43.

Yan, G., Viraraghavan, T., 2001. Heavy metal removal in a biosorption column by immobilized M. rouxii biomass. Bioresour. Technol. 78, 243-249.

Yoon, Y.H., Nelson, J.H., 1984. Application of gas adsorption kinetics. I. A theoretical model for respirator cartridge service life. Am. Ind. Hyg. Assoc. J. 45, 509-516.

Yu, H., Zou, W., Chen, J., Chen, H., Yu, Z., Huang, J., Tang, H., Wei, X., Gao, B., 2019 Biochar amendment improves crop production in problem soils: a review. J. Environ. Manage. 232, 8-21. 